\title{
Transient elastography is useful for evaluating hepatocellular carcinoma development during entecavir treatment of chronic hepatitis $B$ virus infection
}

\author{
Masaaki Shimada*, Hiroaki Iwase, Noboru Hirashima, Nobumitsu Ryuge and Noboru Urata \\ Department of Gastroenterology, National Hospital Organization, Nagoya Medical Center, Nagoya 460-0001, Japan
}

\begin{abstract}
Objective: Chronic hepatitis B virus (HBV) infection leads to cirrhosis and hepatocellular carcinoma (HCC). Entecavir (ETV) is effective for treating patients with HBV infection. However, the process of HCC development in patients treated with ETV remains unclear. We used transient elastography to investigate whether HCC development was correlated with liver stiffness (LS).
\end{abstract}

Methods: This retrospective study enrolled 100 patients with chronic HBV infection who were treated with ETV from August 2007 to November 2015 . The baseline patient characteristics were as follows: average age $54.8 \pm 13.8$ years, 64 men, 11 with cirrhosis, 32 positive for HBe antigen, median HBV DNA level 3.0 log copies/ $\mathrm{mL}$, and treatment duration $55.0 \pm 28.7$ months. One year after the initiation of ETV treatment, laboratory data and viral markers were evaluated. LS values were measured using transient elastography.

Results: HBV DNA became undetectable in 90 patients, and alanine aminotransferase (ALT) levels normalized in 86\%. Alpha-fetoprotein levels decreased from $12.0 \pm 35.7$ to $3.2 \pm 1.4 \mathrm{ng} / \mathrm{mL}$ ( $\mathrm{p}<0.05$ ). HCC developed in seven patients. The cumulative incidence of HCC at 1,3 , and 5 years was $1 \%, 4 \%$, and $6 \%$, respectively. HCC development was not affected by HBV DNA negativity or by ALT level normalization. Patients who developed HCC had a higher rate of cirrhosis and higher LS values ( $\geq 6.8 \mathrm{kPa}$ ) than patients who did not develop HCC (cirrhosis: $57.1 \%$ vs. $7.5 \%$, p < 0.001; LS values $\geq 6.8 \mathrm{kPa}: 83.3 \%$ vs. $16.3 \%$, p < 0.001).

Conclusion: LS values can be useful for the evaluation of HCC development in patients with chronic HBV infection treated with ETV.

\section{Introduction}

Chronic hepatitis B virus (HBV) infection leads to liver cirrhosis, liver failure, and hepatocellular carcinoma (HCC) [1]. Lamivudine (LVD), a first-generation oral nucleoside analogue (NA), significantly reduced the risk of HCC development in a randomized controlled trial [2]. However, LVD leads to a high incidence of drug-resistant mutations and virological relapse [2,3]. Hence, entecavir (ETV) and tenofovir, more effective oral NAs, are now the first-line antiviral agents for patients with chronic HBV infection [4-6] because of their low risk for the development of drug resistance [7,8]. ETV can substantially improve liver function and reduce both cirrhotic complications and HCC development $[9,10]$. However, a randomized controlled ETV treatment study of patients with chronic HBV infection has not been performed, and the suppressive effect of ETV on HCC development remains unclear.

The degree of liver fibrosis is associated with HCC development in patients with chronic HBV infection. The 5-year cumulative HCC development rate was $21.2-59 \%$ in patients with HBV-related cirrhosis [11,12]. Recently, measurement of liver stiffness (LS) using transient elastography has been used as a noninvasive method for evaluating fibrosis instead of the invasive approach of liver biopsy [13]. Measurement of LS with transient elastography is also a predictive tool for HCC development [14].

Therefore, we aimed to investigate whether HCC development was correlated with LS using transient elastography in patients with chronic HBV infection treated with ETV.

\section{Materials and methods}

We retrospectively studied the data of a total of 100 patients with chronic HBV infection who were treated with ETV from August 2007 to November 2015 at the National Hospital Organization Nagoya Medical Center. The patients were followed once every 3-6 months during ETV treatment, and ultrasonography, computed tomography, and magnetic resonance imaging of the abdomen were used for HCC surveillance. One year after the initiation of ETV treatment, liver biochemistry, HBV DNA level, and alpha-fetoprotein (AFP) level were assessed. LS values were measured more than 10 times using transient elastography, and the median value was considered the elastic modulus of the liver.

\section{Statistical analysis}

All data were expressed as the mean \pm standard deviation. Differences were analyzed using paired t-test, Mann-Whitney U-test, and chi-square test. The cumulative incidence of HCC was estimated

Correspondence to: Dr. Masaaki Shimada, MD, Department of Gastroenterology, National Hospital Organization, Nagoya Medical Center, 4-1-1 Sannomaru Naka-ku, Nagoya 460-0001, Japan, Tel: 052-951-1111; Fax: 052-951-0664; E-mail: shimada@nnh.hosp.go.jp

Key words: entecavir, hepatitis B virus, hepatocellular carcinoma, transient elastography

Received: June 21, 2017; Accepted: June 22, 2017; Published: June 25, 2017 
Shimada M (2017) Transient elastography is useful for evaluating hepatocellular carcinoma development during entecavir treatment of chronic hepatitis B virus infection

using the Kaplan-Meier method. Values of $\mathrm{p}<0.05$ were considered statistically significant.

This study was approved by the ethical review board of the National Hospital Organization Nagoya Medical Center.

\section{Results}

The baseline patient characteristics are summarized in Table 1. The average age of patients ( 64 men and 36 women) was $54.8 \pm 13.8$ years. HBV genotypes were measured in 54 patients ( 8 genotype A, 3 genotype $\mathrm{B}$, and 43 genotype $\mathrm{C}$ ). Thirteen patients received LVD, 3 patients received LVD/adefovir, and 84 patients received no drug as a prior treatment. Concerning the severity of liver disease, chronic hepatitis was diagnosed in 89 patients and cirrhosis in 11 patients. $\mathrm{HBe}$ antigen was positive in 32 patients (33\%) and negative in 65 patients (67\%). The median HBV DNA level was $3.0 \log$ copies $/ \mathrm{mL}$, and the treatment duration was $55.0 \pm 28.7$ months.

One year after the initiation of ETV treatment, HBV DNA became undetectable in 90 patients (90\%); alanine aminotransferase (ALT) level significantly decreased from $109.2 \pm 280.5$ to $22.1 \pm 14.8 \mathrm{IU} / \mathrm{L}$ (p $<0.05$ ); normalization of ALT level (30 IU/L or lower) was achieved in $86 \%$; and AFP level significantly decreased from $12.0 \pm 35.7$ to $3.2 \pm 1.4$ $\mathrm{ng} / \mathrm{mL}(\mathrm{p}<0.05)$.

HCC developed in seven patients during the observation period. The average age of these patients (six men and one woman) was $58.0 \pm$ 7.7 years. The total bilirubin level, ALT level, LS value, and occurrence of cirrhosis were significantly higher in patients who developed HCC than in those who did not (total bilirubin level: $1.30 \pm 0.96$ vs. 0.78 $\pm 0.44 \mathrm{mg} / \mathrm{dL}, \mathrm{p}=0.025$; ALT level: $129.0 \pm 129.7$ vs. $107.8 \pm 289.0$ $\mathrm{IU} / \mathrm{L}, \mathrm{p}=0.020$; LS value: $13.3 \pm 11.5$ vs. $5.2 \pm 4.2 \mathrm{kPa}, \mathrm{p}=0.024$; without cirrhosis/with cirrhosis: $3 / 4$ vs. $86 / 7, \mathrm{p}<0.001$ ) (Table 2 ). The cumulative incidence of $\mathrm{HCC}$ at 1,3 , and 5 years was $1 \%, 4 \%$, and $6 \%$, respectively (Figure 1). The average time to HCC development was 36.3 \pm 33.8 months from the initiation of ETV treatment.

Among all patients, HCC development was not affected by ALT level normalization or by HBV DNA negativity 1 year after the initiation of ETV treatment (ALT level normalization: $71.4 \%$ vs. $87.0 \%, \mathrm{p}=0.249, \mathrm{HBV}$ DNA negativity: $100 \%$ vs. $89.2 \%, \mathrm{p}=0.360$ ) (Figures 2 and 3 ).

Patients who developed HCC had higher LS values ( $\geq 6.8 \mathrm{kPa})$ than those who did not (LS values $\geq 6.8 \mathrm{kPa}: 83.3 \%$ vs. $16.3 \%, \mathrm{p}<0.001$ ) (Figure 4).

Table 1. The baseline patient characteristics.

\begin{tabular}{|l|l|l|}
\hline Age & Years & $54.8 \pm 13.8$ \\
\hline Gender & male/female & $64 / 36$ \\
\hline HBV genotype & $\mathrm{A} / \mathrm{B} / \mathrm{C}$ & $8(14.8 \%) / 3(5.6 \%) / 43(79.6 \%)$ \\
\hline Prior treatment & $\mathrm{LVD} / \mathrm{LVD}+\mathrm{ADV} /$ not treated & $13 / 03 / 84$ \\
\hline Severity of liver disease & no cirrhosis/cirrhosis & $89 / 11$ \\
\hline HBeAg & positive/negative & $32(33 \%) / 65(67 \%)$ \\
\hline HBV DNA & log copies/mL (median) & 0.3 \\
\hline Total bilirubin & $\mathrm{mg} / \mathrm{dL}$ & $0.82 \pm 0.50$ \\
\hline Albumin & $\mathrm{g} / \mathrm{dL}$ & $4.16 \pm 0.55$ \\
\hline Platelet & $\times 10^{3} / \mathrm{mm}^{3}$ & $206 \pm 88$ \\
\hline ALT & $\mathrm{IU} / \mathrm{L}$ & $109.2 \pm 280.5$ \\
\hline$\gamma$-GTP & $\mathrm{IU} / \mathrm{L}$ & $70.9 \pm 104.0$ \\
\hline AFP & $\mathrm{ng} / \mathrm{mL}$ & $12.0 \pm 35.7$ \\
\hline Observation period & $\mathrm{months}$ & $550 \pm 28.7$ \\
\hline $\begin{array}{l}\text { Data are expressed as number } \text { or mean } \pm \text { SD, } \\
\text { HBV: Hepatitis B Virus; }\end{array}$ & LVD: Lamivudine; ADV: Adefovir; ALT: Alanine \\
Aminotransferase: GTP: $\gamma$-glutamyltransferase; AFP: $\alpha$-fetoprotein.
\end{tabular}

Table 2. Evaluation of the baseline characteristics according to HCC development.

\begin{tabular}{|l|l|l|l|l|}
\hline & & $\begin{array}{l}\text { HCC } \\
\text { development }\end{array}$ & HCC-free & P-value \\
\cline { 3 - 4 } & & years & $\mathrm{n}=93$ & \\
\hline Age & $58.0 \pm 7.7$ & $54.5 \pm 14.2$ & 0.552 \\
\hline Gender & male/female & $6 / 1$ & $58 / 35$ & 0.215 \\
\hline HBV DNA & $\begin{array}{l}\text { log copies/mL } \\
\text { (median) }\end{array}$ & 6.1 & 3 & 0.483 \\
\hline HBV genotype & $\mathrm{A} / \mathrm{B} / \mathrm{C}$ & $0 / 0 / 5$ & $8 / 3 / 38$ & 0.494 \\
\hline HBBeAg & positive/negative & $3 / 4$ & $29 / 61$ & 0.564 \\
\hline Total bilirubin & $\mathrm{mg} / \mathrm{dL}$ & $1.30 \pm 0.96$ & $0.78 \pm 0.44$ & 0.025 \\
\hline Albumin & $\mathrm{mg} / \mathrm{dL}$ & $3.90 \pm 0.61$ & $4.18 \pm 0.55$ & 0.239 \\
\hline Platelet & $\times 10^{3} / \mathrm{mm}{ }^{3}$ & $154 \pm 78$ & $210 \pm 88$ & 0.056 \\
\hline ALT & $\mathrm{IU} / \mathrm{L}$ & $129.0 \pm 129.7$ & $107.8 \pm 289.0$ & 0.020 \\
\hline AFP & $\mathrm{Ng} / \mathrm{mL}$ & $9.8 \pm 10.1$ & $12.2 \pm 36.8$ & 0.184 \\
\hline LS & $\mathrm{kPa}$ & $13.3 \pm 11.5$ & $5.2 \pm 4.2$ & 0.024 \\
\hline $\begin{array}{l}\text { Severity of liver } \\
\text { disease }\end{array}$ & $\begin{array}{l}\text { no cirrhosis/ } \\
\text { cirrhosis }\end{array}$ & $3 / 4$ & $86 / 7$ & $<0.001$ \\
\hline & & & & \\
\hline
\end{tabular}

\section{Discussion}

According to the Japan Society of Hepatology guidelines for the management of HBV infection (second edition), the treatment goal of antiviral therapy for persistent HBV infection is to improve the life expectancy and quality of life of patients with HBV infection. In other words, the treatment goal of antiviral therapy in patients with persistent HBV infection should be to inhibit the activity of hepatitis and the progression of hepatic fibrosis in order to prevent chronic liver failure and reduce the risk of HCC, thereby improving the life expectancy and quality of life of patients with HBV infection. Thus, the treatment goal should be to attain an HBV DNA negative status for both chronic hepatitis and cirrhosis cases [15]. ETV is a more potent and more highly selective inhibitor of HBV DNA polymerase with a lower risk for drug-resistant mutations than LVD [16-18]. In a previous study, the cumulative rates of undetectable HBV DNA level was $81.1 \%$ and normalization of ALT level was achieved in $84 \%$ at 1 year after the initiation of ETV treatment [19]. In this study, the rate of undetectable HBV DNA level and the normalization of ALT level at 1 year after the initiation of ETV treatment were similar to that of previous results. However, although an undetectable HBV DNA level and ALT level normalization are achieved with ETV treatment, complete elimination of intracellular HBV remains difficult [20,21]. It was reported that although ETV can considerably reduce the risk of HCC development [9], HCC development persists, and the details remain unclear. In a recent report, the cumulative incidence of HCC was not affected by HBV DNA negativity or by ALT level normalization at 24 weeks [22]. In this study, HCC developed in seven patients, and neither a virological response nor biochemical response at 1 year after ETV treatment affected HCC development among the patients.

The degree of liver fibrosis is strongly associated with the risk of HCC in patients with chronic HBV infection [23]. Liver biopsy has been the most widely used method for evaluating the degree of liver fibrosis; however, as it is invasive, a noninvasive tool remains desired. Recently, transient elastography was reported as a noninvasive tool for the assessment of liver fibrosis [13]. The measurement of LS values using transient elastography in patients with HBV with complete virological response on antiviral therapy is useful for predicting the risk of development of liver-related events including HCC [14]. A previous study reported that the median LS values from transient elastography (F0/F1: $5.4 \mathrm{kPa}, \mathrm{F} 2: 6.8 \mathrm{kPa}, \mathrm{F} 3: 10.3 \mathrm{kPa}$, and F4: $17.6 \mathrm{kPa}$ ) were correlated with the stage of liver fibrosis in patients with chronic 


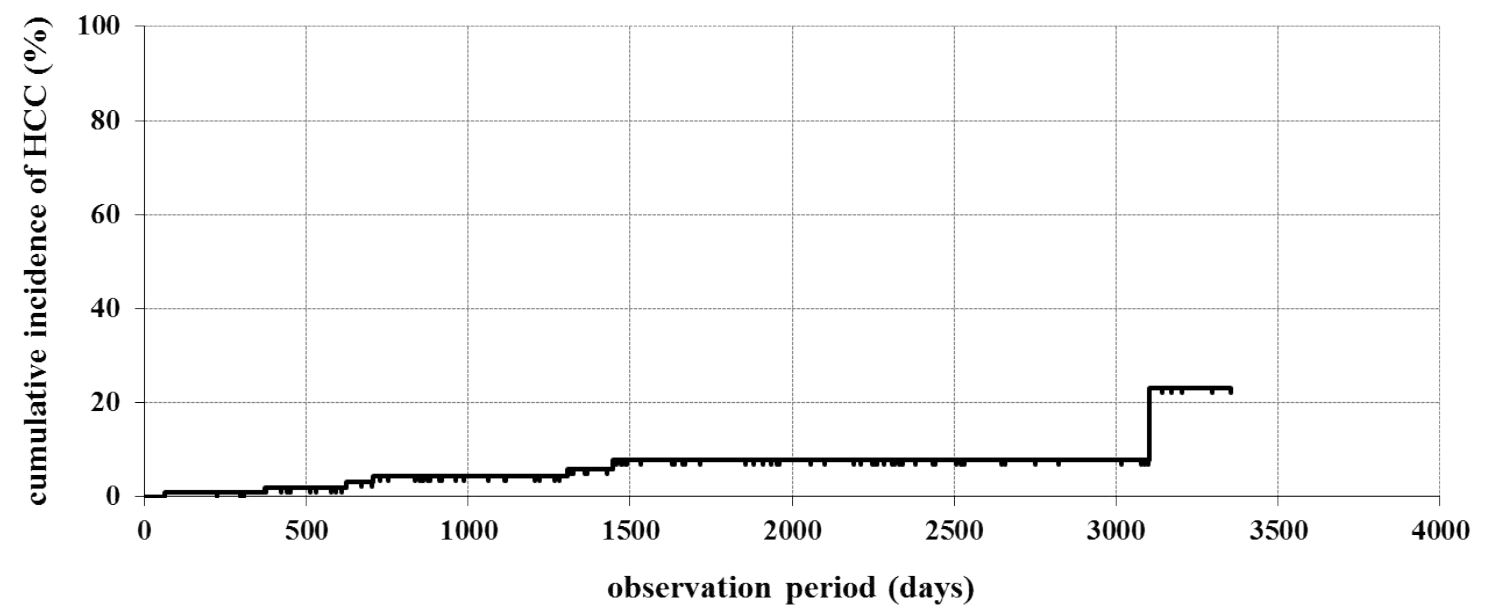

Figure 1. The cumulative incidence of $\mathrm{HCC}$ at 1,3 , and 5 years was $1 \%, 4 \%$, and $6 \%$ respectively.

100

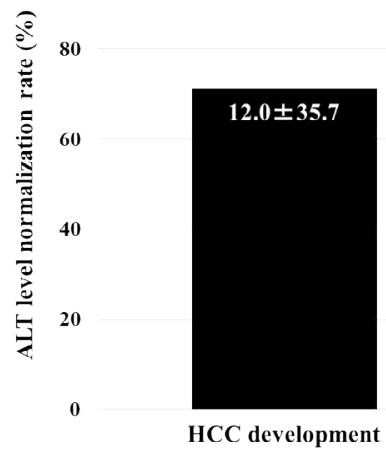

Figure 2. HCC development was not affected by ALT level normalization.

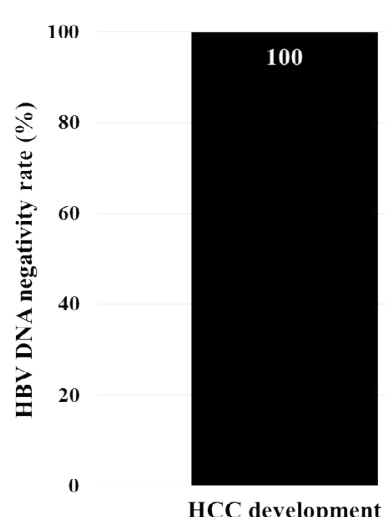

Figure 3. HCC development was not affected by HBV DNA negativity.

hepatitis C [24]. To determine whether transient elastography is useful for the evaluation of HCC development, we measured LS values using this method after the initiation of ETV treatment for both patients with and without HCC development. The results showed that patients who developed HCC had higher LS values $(\geq 6.8 \mathrm{kPa})$ than those who did not.

Although HCC development was not affected by ALT level normalization or by HBV DNA negativity during ETV treatment
100

$\mathrm{p}<\mathbf{0 . 0 0 1}$

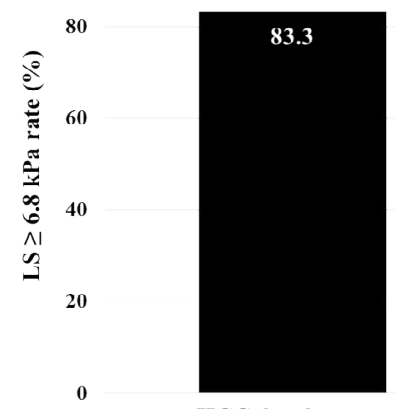

HCC development

\section{3}

HCC-free
Figure 4. Patients who developed HCC had higher LS values $(\geq 6.8 \mathrm{kPa})$ than those who did not (LS values $\geq 6.8 \mathrm{kPa}: 83.3 \%$ vs. $16.3 \%$, p $<0.001$ ).

among the patients, the measurement of LS values using transient elastography was useful for predicting the development of HCC. Therefore, we believe that attention should be paid to the incidence of HCC development during ETV treatment in patients with continuously high LS values $(\geq 6.8 \mathrm{kPa})$.

This was a retrospective study at a single institution. In the future, a larger, multicenter prospective study should be performed to confirm our findings.

In conclusion, LS values measured using transient elastography can be useful for the evaluation of HCC development in patients with chronic HBV infection treated with ETV.

\section{References}

1. Ringelhan M, Heikenwalder M, Protzer U (2013) Direct effects of hepatitis B virusencoded proteins and chronic infection in liver cancer development. Dig Dis31:138151. [Crossref]

2. LiawYF, Sung JJ, Chow WC, Farrell G, Lee CZ, et al. (2004) Lamivudine for patients with chronic hepatitis B and advanced liver disease. N Engl J Med 351: 1521-1531. [Crossref]

3. Wong VW, Wong GL, Chim AM, Choi PC, Chan AW, et al. (2009) Surrogate end points and long-term outcome in patients with chronic hepatitis B. Clin GastroenterolHepatol7: 1113-1120.[Crossref]

4. Liaw YE, Leung N, Kao JH, Piratvisuth T, Gane E, et al. (2008) Asian-Pacific consensus statement on the management of chronic hepatitis B: a 2008 update. HepatolInt2:263-283. [Crossref] 

infection

5. Lok AS, McMahon BJ (2009) Chronic hepatitis B: update 2009. Hepatology 50: 661662.[Crossref]

6. European Association For The Study Of The Liver (2012) EASL clinical practice guidelines: Management of chronic hepatitis B virus infection. J Hepatol 57: 167-185. [Crossref]

7. Chang TT, Lai CL, Kew Yoon S, Lee SS, Coelho HS, et al. (2010) Entecavir treatment for up to 5 years in patients with hepatitis B e antigen-positive chronic hepatitis B. Hepatology 51: 422-430. [Crossref]

8. Wong GL, Wong VW, Chan HY, Tse PC, Wong J, et al. (2012) Undetectable HBV DNA at month 12 of entecavir treatment predicts maintained vira suppression and $\mathrm{HBeAg}$ seroconversion in chronic hepatitis B patients at 3 years. Aliment Pharmacol Ther 35: 1326-1335. [Crossref]

9. Wong GL, Chan HL, Mak CW, Lee SK, Ip ZM, et al. (2013) Entecavir treatment reduces hepatic events and deaths in chronic hepatitis $B$ patients with liver cirrhosis. Hepatology 58: 1537-1547. [Crossref]

10. Yasunaka T, Ikeda F, Wada N, Morimoto Y, Fujioka S, et al. (2016) Entecavir Reduces Hepatocarcinogenesis in Chronic Hepatitis B Patients. Acta Med Okayama 70: 1-12. [Crossref]

11. Kato Y, Nakata K, Omagari K, Furukawa R, Kusumoto Y, et al. (1994) Risk of hepatocellular carcinoma in patients with cirrhosis in Japan. Analysis of infectious hepatitis viruses. Cancer 74: 2234-2238. [Crossref]

12. Lo KJ, Tong MJ, Chien MC, Tsai YT, Liaw YF, et al. (1982) The natural course of hepatitis B surface antigen-positive chronic active hepatitis in Taiwan. J Infect Dis 146: 205-210. [Crossref]

13. Ganne-Carrie N, Ziol M, de Ledinghen V, Douvin C, Marcellin P, et al. (2006) Accuracy of liver stiffness measurement for the diagnosis of cirrhosis in patients with chronic liver diseases. Hepatology 44: 1511-1517. [Crossref]

14. Lee HW, Yoo EJ, Kim BK, Kim SU, Park JY et al. (2014) Prediction of development of liver-related events by transient elastography in hepatitis B patients with complete virological response on antiviral therapy. Am J Gastroenterol 109: 1241-1249. [Crossref]
15. Drafting committee for hepatitis management guidelines and the Japanese society of hepatology (2014) JSH guidelines for the management of hepatitis B virus infection. Hepatology Research 44: 1-58.

16. Innaimo SF, Seifer M, Bisacchi GS, Standring DN, Zahler R, et al. (1997) Identification of BMS-200475 as a potent and selective inhibitor of hepatitis B virus. Antimicrob Agents Chemother 41: 1444-1448.[Crossref]

17. Chang TT, Gish RG, de Man R, Gadano A, Sollano J, et al. (2006) A comparison of entecavir and lamivudine for HBeAg-positive chronic hepatitis B. N Engl J Med 354 1001-1010.[Crossref]

18. Lai CL, Shouval D, Lok AS, Chang TT, Cheinquer H, et al. (2006) Entecavir versus lamivudine for patients with HBeAg-negative chronic hepatitis B. N Engl J Med 354: 1011-1020.[Crossref]

19. Yuen MF, Seto WK, Fung J, Wong DK, Yuen JC, et al. (2011) Three years of continuous entecavir therapy in treatment-naïve chronic hepatitis B patients: viral suppression, viral resistance, and clinical safety. Am J Gastroenterol 106: 1264-1271. [Crossref]

20. Rokuhara A, Tanaka E, Matsumoto A, Kimura T, Yamaura T, et al. (2003) Clinica evaluation of a new enzyme immunoassay for hepatitis B virus core-related antigen: a marker distinct from viral DNA for monitoring lamivudine treatment. $J$ Viral Hepat 10: 324-330. [Crossref]

21. Werle-Lapostolle B, Bowden S, Locarnini S, Wursthorn K, Petersen J, et al. (2004) Persistence of cccDNA during the natural history of chronic B and decline during adefovirdipivoxil therapy. Gastroenterology 126: 1750-1758. [Crossref]

22. Yamada R, Hiramatsu N, Oze T, Morishita N, Harada N, et al. (2015) Impact of alphafetoprotein on hepatocellular carcinoma development during entecavir treatment of chronic hepatitis B virus infection. J Gastroenterol 50: 785-794. [Crossref]

23. Hosaka T, Suzuki F, Kobayashi M, Seko Y, Kawamura Y, et al. (2013) Long-term entecavir treatment reduces hepatocellular carcinoma incidence in patients with hepatitis B virus infection. Hepatology 58: 98-107. [Crossref]

24. Kettaneh A, Marcellin P, Douvin C, Poupon R, Ziol M, et al. (2007) Features associated with success rate and performance of fibroscan measurements for the diagnosis of cirrhosis in HCV patients: a prospective study of 935 patients. Journal of Hepatology 46: 628-634. [Crossref]

Copyright: (C2017 Shimada M. This is an open-access article distributed under the terms of the Creative Commons Attribution License, which permits unrestricted use, distribution, and reproduction in any medium, provided the original author and source are credited. 